\title{
Glyoxal yield from isoprene oxidation and relation to formaldehyde: chemical mechanism, constraints from SENEX aircraft observations, and interpretation of OMI satellite data
}

\author{
Christopher Chan Miller ${ }^{1}$, Daniel J. Jacob ${ }^{1,2}$, Eloise A. Marais ${ }^{1}$, Karen Yu ${ }^{2}$, Katherine R. Travis ${ }^{2}$, Patrick S. Kim ${ }^{1}$, \\ Jenny A. Fisher ${ }^{3}$, Lei Zhu ${ }^{2}$, Glenn M. Wolfe ${ }^{4,5}$, Thomas F. Hanisco ${ }^{4}$, Frank N. Keutsch ${ }^{2,6}$, Jennifer Kaiser ${ }^{7, a}$, \\ Kyung-Eun Min ${ }^{8,9, b}$, Steven S. Brown ${ }^{9,10}$, Rebecca A. Washenfelder ${ }^{8,9}$, Gonzalo González Abad ${ }^{11}$, and Kelly Chance ${ }^{11}$ \\ ${ }^{1}$ Department of Earth and Planetary Sciences, Harvard University, Cambridge, MA, USA \\ ${ }^{2}$ School of Engineering and Applied Sciences, Harvard University, Cambridge, MA, USA \\ ${ }^{3}$ School of Chemistry and School of Earth and Environmental Sciences, University of Wollongong, \\ Wollongong, NSW, Australia \\ ${ }^{4}$ Atmospheric Chemistry and Dynamics Lab, NASA Goddard Space Flight Center, Greenbelt, MD, USA \\ ${ }^{5}$ Joint Center for Earth Systems Technology, University of Maryland Baltimore County, Baltimore, MD, USA \\ ${ }^{6}$ Department of Chemistry and Chemical Biology, Harvard University, Cambridge, MA, USA \\ ${ }^{7}$ Department of Chemistry, University of Wisconsin Madison, Madison, WI, USA \\ ${ }^{8}$ Cooperative Institute for Research in Environmental Sciences, University of Colorado Boulder, Boulder, CO, USA \\ ${ }^{9}$ Chemical Sciences Division, NOAA Earth System Research Laboratory, Boulder, CO, USA \\ ${ }^{10}$ Department of Chemistry and Biochemistry, University of Colorado, Boulder, CO, USA \\ ${ }^{11}$ Harvard-Smithsonian Center for Astrophysics, Cambridge, MA, USA \\ ${ }^{a}$ now at: School of Engineering and Applied Sciences, Harvard University, Cambridge, MA, USA \\ ${ }^{b}$ now at: School of Earth Sciences and Environmental Engineering, Gwangju Institute of Science and Technology, \\ Gwangju, South Korea
}

Correspondence to: Daniel J. Jacob (djacob@fas.harvard.edu)

Received: 23 November 2016 - Discussion started: 29 November 2016

Revised: 5 June 2017 - Accepted: 7 June 2017 - Published: 18 July 2017

\begin{abstract}
Glyoxal (CHOCHO) is produced in the atmosphere by the oxidation of volatile organic compounds (VOCs). Like formaldehyde (HCHO), another VOC oxidation product, it is measurable from space by solar backscatter. Isoprene emitted by vegetation is the dominant source of $\mathrm{CHOCHO}$ and $\mathrm{HCHO}$ in most of the world. We use aircraft observations of $\mathrm{CHOCHO}$ and $\mathrm{HCHO}$ from the SENEX campaign over the southeast US in summer 2013 to better understand the $\mathrm{CHOCHO}$ time-dependent yield from isoprene oxidation, its dependence on nitrogen oxides $\left(\mathrm{NO}_{x} \equiv \mathrm{NO}+\mathrm{NO}_{2}\right)$, the behavior of the CHOCHO-HCHO relationship, the quality of OMI CHOCHO satellite observations, and the implications for using $\mathrm{CHOCHO}$ observations from space as constraints on isoprene emissions. We simulate the SENEX and OMI observations with the Goddard
\end{abstract}

Earth Observing System chemical transport model (GEOS$\mathrm{Chem}$ ) featuring a new chemical mechanism for $\mathrm{CHOCHO}$ formation from isoprene. The mechanism includes prompt $\mathrm{CHOCHO}$ formation under low- $\mathrm{NO}_{x}$ conditions following the isomerization of the isoprene peroxy radical $\left(\mathrm{ISOPO}_{2}\right)$. The SENEX observations provide support for this prompt CHOCHO formation pathway, and are generally consistent with the GEOS-Chem mechanism. Boundary layer CHO$\mathrm{CHO}$ and $\mathrm{HCHO}$ are strongly correlated in the observations and the model, with some departure under low- $\mathrm{NO}_{x}$ conditions due to prompt $\mathrm{CHOCHO}$ formation. SENEX vertical profiles indicate a free-tropospheric $\mathrm{CHOCHO}$ background that is absent from the model. The OMI CHOCHO data provide some support for this free-tropospheric background and show southeast US enhancements consistent with the iso- 
prene source but a factor of 2 too low. Part of this OMI bias is due to excessive surface reflectivities assumed in the retrieval. The OMI CHOCHO and HCHO seasonal data over the southeast US are tightly correlated and provide redundant proxies of isoprene emissions. Higher temporal resolution in future geostationary satellite observations may enable detection of the prompt $\mathrm{CHOCHO}$ production under low- $\mathrm{NO}_{x}$ conditions apparent in the SENEX data.

\section{Introduction}

Glyoxal (CHOCHO) and formaldehyde (HCHO) are shortlived products of the atmospheric oxidation of volatile organic compounds (VOCs). Both are detectable from space by solar backscatter (Chance et al., 2000; Wittrock et al., 2006). Isoprene emitted by terrestrial vegetation accounts for about a third of the global source of non-methane VOCs (NMVOCs Guenther et al., 2012) and drives large enhancements of $\mathrm{CHOCHO}$ and $\mathrm{HCHO}$ in the continental boundary layer (Palmer et al., 2003; Fu et al., 2008). Satellite observations of HCHO have been widely used as a proxy to estimate isoprene emissions (Abbot et al., 2003; Palmer et al., 2006; Millet et al., 2008; Curci et al., 2010; Barkley et al., 2013), but there are uncertainties related to the $\mathrm{HCHO}$ yield from isoprene oxidation (Marais et al., 2012) and the role of other NMVOCs as HCHO precursors (Fu et al., 2007). $\mathrm{CHOCHO}$ observations from space could provide a complementary constraint (Vrekoussis et al., 2009, 2010; Alvarado et al., 2014; Chan Miller et al., 2014). Here we use CHO$\mathrm{CHO}$ and $\mathrm{HCHO}$ aircraft observations over the southeast US from the summer 2013 Southeast Nexus (SENEX) campaign (Warneke et al., 2016), interpreted with the Goddard Earth Observing System chemical transport model (GEOSChem), to test understanding of the $\mathrm{CHOCHO}$ yield from isoprene oxidation, its dependence on nitrogen oxide radicals $\left(\mathrm{NO}_{x} \equiv \mathrm{NO}+\mathrm{NO}_{2}\right)$, and the combined value of the CHOCHO-HCHO pair measured from space to constrain isoprene emissions and chemistry.

Isoprene impacts air quality and climate as a precursor to ozone (Geng et al., 2011) and secondary organic aerosol (SOA Carlton et al., 2009), and also affects concentrations of hydrogen oxide radicals $\left(\mathrm{HO}_{x} \equiv \mathrm{OH}+\mathrm{HO}_{2}\right.$; Peeters and Muller, 2010) and $\mathrm{NO}_{x}$ (Mao et al., 2013; Fisher et al., 2016). Atmospheric oxidation of isoprene by $\mathrm{OH}$ takes place on a timescale of less than an hour to produce organic peroxy radicals $\left(\mathrm{ISOPO}_{2}\right)$. Reaction of $\mathrm{ISOPO}_{2}$ with $\mathrm{NO}$ drives production of ozone and of organic nitrates that serve as a reservoir for $\mathrm{NO}_{x}$ (Browne and Cohen, 2012). At lower $\mathrm{NO}_{x}$ levels, $\mathrm{ISOPO}_{2}$ reacts dominantly with $\mathrm{HO}_{2}$ to produce isoprene epoxydiols (IEPOX) via isoprene peroxides (ISOPOOH; Paulot et al., 2009b), and from there isoprene SOA (Marais et al., 2016). $\mathrm{ISOPO}_{2}$ can also isomerize to generate $\mathrm{HO}_{x}$ radicals (Peeters et al., 2009, 2014; Crounse et al., 2011).

The fate of $\mathrm{ISOPO}_{2}$ determines the production rates and overall yields of CHOCHO and HCHO. Several studies have provided insight on the time- and $\mathrm{NO}_{x}$-dependent yield of HCHO (Palmer et al., 2003; Marais et al., 2012; Wolfe et al., 2016). Under high- $\mathrm{NO}_{x}$ conditions, $\mathrm{HCHO}$ production is sufficiently prompt that observed HCHO columns can be locally related to isoprene emission rates (Palmer et al., 2006). This assumption is the basis of many studies that have used satellite $\mathrm{HCHO}$ observations to constrain isoprene emissions (Palmer et al., 2006; Fu et al., 2007; Millet et al., 2008; Curci et al., 2010). HCHO production is much slower under low$\mathrm{NO}_{x}$ conditions, spatially "smearing" the local relationship between isoprene emissions and HCHO columns. This has been addressed by using concurrent satellite data for $\mathrm{NO}_{2}$ columns to correct the isoprene-HCHO relationship (Marais et al., 2012) or by using adjoint-based inverse modeling to relate $\mathrm{HCHO}$ columns to isoprene emissions including the effect of transport (Fortems-Cheiney et al., 2012).

Isoprene is estimated to account for about $\sim 50 \%$ of global CHOCHO production (Fu et al., 2008), but there is large uncertainty regarding the yield of $\mathrm{CHOCHO}$ from isoprene oxidation. Open fires and aromatic VOCs can also be major sources of CHOCHO (Volkamer et al., 2001; Fu et al., 2008; Chan Miller et al., 2016). Several studies have used the measured $\mathrm{CHOCHO}-\mathrm{HCHO}$ concentration ratio $R_{\mathrm{GF}}=[\mathrm{CHOCHO}] /[\mathrm{HCHO}]$ as an indicator of the dominant VOC precursors. Vrekoussis et al. (2010) found higher $R_{\mathrm{GF}}$ values (>0.04) from GOME-2 satellite observations in regions where biogenic VOCs are dominant, and lower values where anthropogenic VOCs are dominant. However, the opposite behavior is observed in ground-based studies (DiGangi et al., 2012). Our recent CHOCHO retrieval from the OMI satellite instrument (Chan Miller et al., 2014) is in better agreement with surface observations of $\mathrm{CHOCHO}$ and $R_{\mathrm{GF}}$ (Kaiser et al., 2015) compared to those from GOME-2 (Vrekoussis et al., 2010) and SCIAMACHY (Wittrock et al., 2006) as a result of improved background corrections and removal of $\mathrm{NO}_{2}$ interferences. There remains the question of how observed CHOCHO-HCHO relationships are to be interpreted.

The Southeast Nexus (SENEX) aircraft campaign was conducted over the southeast US in June-July 2013. The aircraft had a detailed chemical payload including in situ CHOCHO (Min et al., 2016) and HCHO (Cazorla et al., 2015). Thirteen daytime flights were conducted over the campaign with extensive boundary layer coverage. Li et al. (2016) recently used the SENEX observations to evaluate CHO$\mathrm{CHO}$ formation from isoprene in the AM3 chemical transport model (CTM). They found that the AM3 mechanism had closer agreement with observations than the explicit Master Chemical Mechanism v3.3.1 (MCMv3.3.1; Jenkin et al., 2015), and suggested that CHOCHO yields from isoprene epoxydiols are underestimated in MCMv3.3.1. Here 
we take a more rigorous look at potential missing pathways in MCMv3.3.1. In doing so, we present an improved chemical mechanism for $\mathrm{CHOCHO}$ formation from isoprene for the GEOS-Chem CTM, and evaluate it against the SENEX observations, including the time and $\mathrm{NO}_{x}$ dependence of the $\mathrm{CHOCHO}$ yield from isoprene. We discuss the implications of the new mechanism for the interpretation of satellite observations, and present a first validation of the $\mathrm{CHOCHO}$ retrieval from the OMI satellite instrument (Chan Miller et al., 2014).

\section{GEOS-Chem model description}

\subsection{General description}

We use the same version of GEOS-Chem v9.2 (http://www. geos-chem.org) that has been used previously to interpret chemical observations from the NASA SEAC ${ }^{4}$ RS aircraft campaign conducted in the same southeast US region in August-September 2013 (Travis et al., 2016; Fisher et al., 2016). The model is driven by assimilated meteorological data with $0.25^{\circ} \times 0.3125^{\circ}$ horizontal resolution from the Goddard Earth Observing System (GEOS-FP) reanalysis product (Molod et al., 2012). The native $0.25^{\circ} \times 0.3125^{\circ}$ resolution is retained in GEOS-Chem over the North American domain $\left(130-60^{\circ} \mathrm{W}, 9.75-60^{\circ} \mathrm{N}\right)$, nested within a global simulation at $2^{\circ} \times 2.5^{\circ}$ resolution (Kim et al., 2015). Isoprene chemistry in GEOS-Chem v9.2 is as described by Mao et al. (2013), but the SEAC ${ }^{4} \mathrm{RS}$ simulation includes a number of updates described by Travis et al. (2016) and Fisher et al. (2016). The simulation presented here includes further modifications relevant to $\mathrm{CHOCHO}$, listed in the Supplement (Table S1) and summarized below. Evaluation of the model with SEAC ${ }^{4} \mathrm{RS}$ observations has been presented by Kim et al. (2015) for aerosols, Travis et al. (2016) for ozone and $\mathrm{NO}_{x}$, Fisher et al. (2016) for organic nitrates, Marais et al. (2016) for isoprene SOA, and Zhu et al. (2016) for HCHO including satellite validation.

Isoprene emissions in the model are from MEGANv2.1 (Guenther et al., 2012) with a $15 \%$ reduction (Kim et al., 2015), and $\mathrm{NO}_{x}$ emissions are as described by Travis et al. (2016) including a $50 \%$ decrease in the anthropogenic source relative to the 2011 National Emission Inventory of the US Environmental Protection Agency. Yu et al. (2016) pointed out that isoprene and $\mathrm{NO}_{x}$ emissions in the southeast US are spatially segregated and show that the $0.25^{\circ} \times 0.3125^{\circ}$ resolution of GEOS-Chem is adequate for separating the populations of high- and low- $\mathrm{NO}_{x}$ conditions for isoprene oxidation.

\subsection{CHOCHO formation from isoprene and loss}

Figure 1 shows the $\mathrm{CHOCHO}$ formation pathways from isoprene oxidation by $\mathrm{OH}$ (the main isoprene sink) as implemented in this work. Oxidation is initiated by $\mathrm{OH}$ addition to the terminal carbons of the isoprene double bonds (positions 1 and 4, Fig. 1). Isoprene peroxy radicals $\left(\mathrm{ISOPO}_{2}\right)$ are formed by $\mathrm{O}_{2}$ addition to the carbon either in $\beta$ or $\delta$ to the hydroxyl carbon. $\mathrm{ISOPO}_{2}$ reacts with $\mathrm{NO}$ and $\mathrm{HO}_{2}$, and also isomerizes. Together these pathways represent $92 \%$ of $\mathrm{ISOPO}_{2}$ loss, with the remainder due to reactions with organic peroxy radicals.

Under high- $\mathrm{NO}_{x}$ conditions, $\mathrm{CHOCHO}$ is produced promptly via products of the $\delta$ isomers (HC5, DIBOO; Paulot et al., 2009a; Galloway et al., 2011). CHOCHO production via the $\beta$ isomers is slower, due to the intermediary production of methylvinylketone (MVK) followed by glycolaldehyde (GLYC). GEOS-Chem originally had a fixed $\delta$ vs. $\beta$ branching ratio of $24 \%$ for the reaction of $\mathrm{ISOPO}_{2}+\mathrm{NO}$, based on the chamber experiments of Paulot et al. (2009a). However recent work has shown that $\mathrm{O}_{2}$ addition to the isoprene- $\mathrm{OH}$ adducts is reversible (pink pathway, Fig. 1), allowing interconversion between $\beta$ and $\delta \mathrm{ISOPO}_{2}$ isomers (Peeters et al., 2009, 2014; Crounse et al., 2011). Isomers of $\beta$ are heavily favored at equilibrium, accounting for $\sim 95 \%$ of $\mathrm{ISOPO}_{2}$ (Peeters et al., 2014). The experimental conditions in Paulot et al. (2009a) used high $\mathrm{NO}_{x}$ concentrations $(\sim 500 \mathrm{ppbv})$. This implies short $\mathrm{ISOPO}_{2}$ lifetimes, and thus may not reflect the degree of isomer interconversion seen at ambient oxidant levels. Here we adopt a $\delta$-ISOPO 2 branching ratio of $10 \%$, following Fisher et al. (2016), to match SEAC ${ }^{4} \mathrm{RS}$ observations of organic nitrates produced through the $\delta$-ISOPO $2+\mathrm{NO}$ pathway.

$\mathrm{CHOCHO}$ forms under low- $\mathrm{NO}_{x}$ conditions through isoprene epoxydiols (IEPOX) and through the $\mathrm{ISOPO}_{2}$ isomerization pathway. IEPOX forms as a second-generation non-radical product of isoprene oxidation via ISOPOOH, and thus represents a slow $\mathrm{CHOCHO}$ formation pathway. IEPOX isomer fractions in GEOS-Chem are based on equilibrium $\delta / \beta \mathrm{ISOPO}_{2}$ branching ratios (Bates et al., 2014; Travis et al., 2016). At low $\mathrm{NO}_{x}$ levels the $\mathrm{ISOPO}_{2}$ lifetime is sufficiently long for equilibrium to be reached (Peeters et al., 2014). ISOPO 2 isomerization in the previous GEOSChem mechanism of Travis et al. (2016) produced solely hydroperoxyaldehydes (HPALDs), but here we also include the formation of dihydroperoxy $\alpha$-formyl peroxy radicals (di-HPCARPs; Peeters et al., 2014) following MCMv3.3.1. di-HPCARPs in MCMv3.3.1 have a low CHOCHO yield, but here we introduce a $(1,5) \mathrm{H}$-shift isomerization of diHPCARPs that could be competitive with the $(1,4) \mathrm{H}$-shift isomerization due to the presence of the terminal-peroxide functional group (Crounse et al., 2013). The resulting di-hydroperoxide dicarbonyl compound (DHDC) product quickly photolyzes to produce $\mathrm{CHOCHO}$, analogous to the mechanisms proposed for HPALDs (Peeters et al., 2014) and carbonyl nitrates (Müller et al., 2014). As shown below, we find that this pathway can explain SENEX observations of prompt $\mathrm{CHOCHO}$ production under low- $\mathrm{NO}_{x}$ conditions.

The mechanism presented here differs substantially from the AM3 mechanism previously used by Li et al. (2016) 


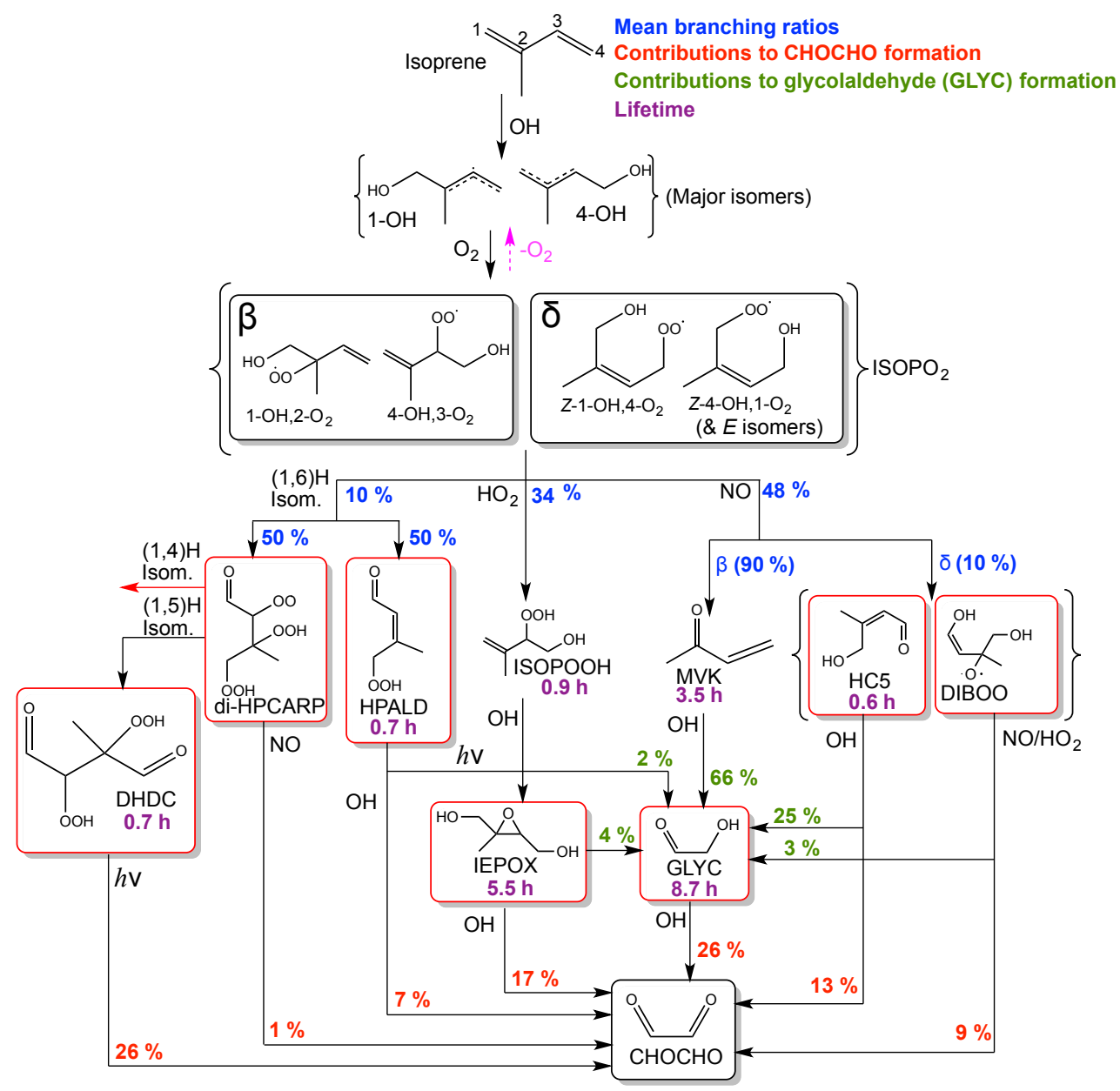

Figure 1. Pathways for glyoxal (CHOCHO) formation from isoprene oxidation in GEOS-Chem as implemented in this work. Only species relevant to $\mathrm{CHOCHO}$ formation are shown. Branching ratios, species lifetimes, and contributions to glyoxal and glycolaldehyde (GLYC) formation from each boxed species are mean values over the southeast US $\left(96.25-73.75^{\circ} \mathrm{W}, 29-41^{\circ} \mathrm{N}\right)$ during the SENEX campaign ( 1 June10 July 2013). Species lifetimes are shown for an $\mathrm{OH}$ concentration of $4 \times 10^{6}$ molecules $\mathrm{cm}^{-3}$.

to analyze the SENEX observations. Li et al. (2016) tested branching ratios of 22 and $0 \%$ for $\delta$-ISOPO $2+\mathrm{NO}$, with the latter intended to reflect $\mathrm{ISOPO}_{2}$ isomer interconversion. The $10 \%$ branching ratio in this study is constrained by SEAC ${ }^{4} \mathrm{RS}$ organic nitrate observations (Fisher et al., 2016). $\mathrm{Li}$ et al. (2016) report a CHOCHO yield from GLYC oxidation (Sect. S1 in the Supplement), which is mainly due to a lower $\mathrm{CHOCHO}$ yield from GLYC $+\mathrm{OH}(13 \%$ vs. $20 \%)$. Their yield of CHOCHO from IEPOX is $28 \%$, much higher than can be accommodated by yields of hydroxyacetone derived from IEPOX oxidation chamber experiments (Bates et al., 2014) (the expected coproduct of $\mathrm{CHOCHO}$ via this pathway, Sect. S2). Following Travis et al. (2016), we set the $\mathrm{CHOCHO}$ yield from IEPOX to the corresponding hydroxyacetone yields reported by Bates et al. (2014) $\left(8.5 \%\right.$ via $\mathrm{HO}_{2}$ and $8.8 \%$ via NO). Finally AM3 assumes $25 \% \mathrm{CHOCHO}$ yield from HPALD photolysis following Stavrakou et al. (2010), which has been used in many past studies (Mao et al.,
2013; Marais et al., 2016). However HPALD photolysis is not expected to yield CHOCHO (Sect. S3). The CHOCHO formation pathway via DHDC proposed here can be justified from existing literature (Sect. S3). Inclusion of DHDC increases the yield of $\mathrm{CHOCHO}$ via $\mathrm{ISOPO}_{2}$ isomerization by $18 \%$, which is comparable to the AM3 yield.

Li et al. (2016) found that $\mathrm{CHOCHO}$ concentrations are sensitive to aerosol reactive uptake. Our standard model simulation does not include this uptake, but we conducted a sensitivity simulation with a reactive uptake coefficient $\gamma=$ $2 \times 10^{-3}$ from Li et al. (2016). We find that CHOCHO concentrations decrease by only $10 \%$ on average (Sect. S4) because competing $\mathrm{CHOCHO}$ sinks from reaction with $\mathrm{OH}$ and photolysis are fast. 
(a) $\mathrm{ISOPO}_{2}$ fate

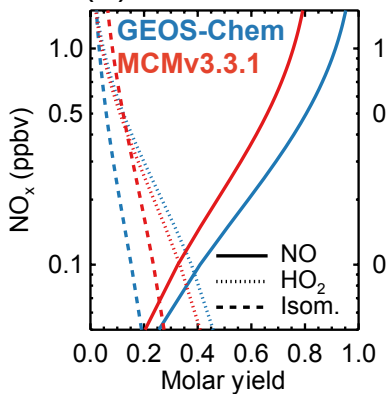

(b) $\mathrm{CHOCHO}$ yield

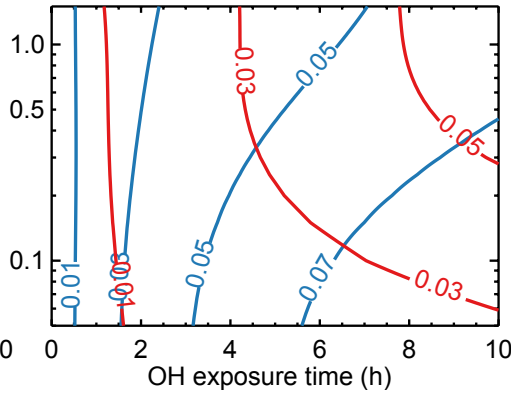

(c) $\mathrm{HCHO}$ yield

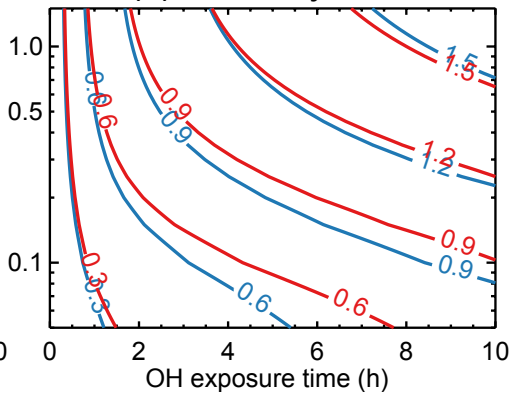

Figure 2. Cumulative time- and $\mathrm{NO}_{x}$-dependent molar yields of $\mathrm{CHOCHO}$ and $\mathrm{HCHO}$ from isoprene oxidation in the GEOS-Chem and MCM3.3.1 chemical mechanisms. Results are from box model simulations with fixed $\mathrm{NO}_{x}$ concentrations as described in the text, and are presented as functions of the imposed $\mathrm{NO}_{x}$ concentration (vertical axis). Panel (a) shows the isoprene peroxy radical (ISOPO 2$)$ branching ratios for reaction with $\mathrm{NO}, \mathrm{HO}_{2}$, and isomerization. Panels $(\mathbf{b}, \mathbf{c})$ show the time-dependent cumulative yields of $\mathrm{CHOCHO}$ and $\mathrm{HCHO}$, where time is normalized by $\mathrm{OH}$ exposure (Eq. 1). "OH exposure time" is equivalent to time for a constant $[\mathrm{OH}]=4 \times 10^{6} \mathrm{molecules} \mathrm{cm}^{-3}$.

\subsection{Time- and $\mathrm{NO}_{x}$-dependent $\mathrm{CHOCHO}$ and $\mathrm{HCHO}$ yields from isoprene}

Understanding the time- and $\mathrm{NO}_{x}$-dependent yields of $\mathrm{CHO}$ $\mathrm{CHO}$ and $\mathrm{HCHO}$ from isoprene oxidation is critical for interpreting observed $\mathrm{CHOCHO}$ and $\mathrm{HCHO}$ columns from space in terms of isoprene emissions. Here we examine time-dependent $\mathrm{CHOCHO}$ and $\mathrm{HCHO}$ molar yields in the GEOS-Chem and MCMv3.3.1 chemical mechanisms using the Dynamically Simple Model of Atmospheric Chemical Complexity (DSMACC) box model (Emmerson and Evans, 2009). Simulations are initiated at 09:00 LT with $1 \mathrm{ppbv}$ isoprene, $40 \mathrm{ppbv} \mathrm{O}_{3}$, and $100 \mathrm{ppbv} \mathrm{CO} . \mathrm{NO}_{x}$ concentrations are held at fixed values. Photolysis rates are calculated for clear sky with the TUV radiative transfer model (Madronich, 1987). To correct for differences in time-dependent yields associated with differences in $\mathrm{OH}$ concentrations, we reference GEOS-Chem and MCMv3.3.1 results to a common "OH exposure time" variable $\left(t_{\mathrm{OH}}\right)$ :

$t_{\mathrm{OH}}=\frac{1}{[\mathrm{OH}]_{\mathrm{ref}}} \int_{0}^{t}[\mathrm{OH}]\left(t^{\prime}\right) \mathrm{d} t^{\prime}$.

Here $[\mathrm{OH}](t)$ is the $\mathrm{OH}$ concentration simulated in the box model, and $[\mathrm{OH}]_{\mathrm{ref}}=4 \times 10^{6}$ molecules $\mathrm{cm}^{-3}$ is a reference $\mathrm{OH}$ concentration representative of summer daytime conditions over the southeast US (Wolfe et al., 2016). For a fixed $[\mathrm{OH}]=4 \times 10^{6}$ molecules $\mathrm{cm}^{-3}, t_{\mathrm{OH}}$ represents the actual time.

Figure 2 shows the time- and $\mathrm{NO}_{x}$-dependent cumulative molar yields of $\mathrm{CHOCHO}$ and $\mathrm{HCHO}$ in GEOS-Chem and MCMv3.3.1. The branching ratio of $\mathrm{ISOPO}_{2}$ as a function of $\mathrm{NO}_{x}$ is also shown. The time-dependent $\mathrm{HCHO}$ yields in both mechanisms are similar under high- $\mathrm{NO}_{x}$ conditions. Additional confidence in the $\mathrm{HCHO}$ yield under these conditions is offered by the ability of GEOS-Chem to reproduce the observed correlation between $\mathrm{HCHO}$ and isoprene organic nitrates (Mao et al., 2013; Fisher et al., 2016). The $\mathrm{HCHO}$ yield is lower under low- $\mathrm{NO}_{x}$ conditions in both mechanisms, and overall the difference between them is minor.

There is far more disagreement between the two mechanisms for $\mathrm{CHOCHO}$ yields. Under high- $\mathrm{NO}_{x}$ conditions, GEOS-Chem produces $\mathrm{CHOCHO}$ rapidly in the first $2 \mathrm{~h}$ due to its higher $\delta$-ISOPO $2+\mathrm{NO}$ branching ratio ( $10 \%$ in GEOSChem vs. $3.4 \%$ in MCMv3.3.1). This is compensated at longer $\mathrm{OH}$ exposure times by higher GLYC yields from isoprene in MCMv3.3.1. GEOS-Chem produces higher ultimate yields of $\mathrm{CHOCHO}$ under low- $\mathrm{NO}_{x}$ conditions mainly due to DHDC formation and subsequent photolysis, neither of which are included in MCMv3.3.1. The $\mathrm{NO}_{x}$-dependence of the CHOCHO yield in MCMv3.3.1 is similar to that of $\mathrm{HCHO}$, implying that $\mathrm{CHOCHO}$ and $\mathrm{HCHO}$ observations would provide redundant information on isoprene emissions. The SENEX observations indicate that $\mathrm{CHOCHO}$ yields under low- $\mathrm{NO}_{x}$ conditions are too low in MCMv3.3.1, as discussed below. In GEOS-Chem, by contrast, the CHOCHO and $\mathrm{HCHO}$ yields show opposite dependences on $\mathrm{NO}_{x}$, implying that they could provide complementary information on isoprene emissions.

\section{Constraints from SENEX observations}

Figure 3 shows the observed and simulated median vertical profiles of $\mathrm{CHOCHO}, \mathrm{HCHO}$, and $\mathrm{NO}_{x}$ concentrations along the SENEX flight tracks. Figure 4 shows maps of concentrations below $1 \mathrm{~km}$ altitude (above ground level) taken as the mixed layer. Here and elsewhere we only include daytime observations (10:00-17:00 LT) and exclude targeted sampling of biomass burning plumes (diagnosed by acetonitrile concentrations above $200 \mathrm{pptv}$ ). CHOCHO, HCHO, and $\mathrm{NO}_{x}$ were measured by the Airborne Cavity Enhanced 

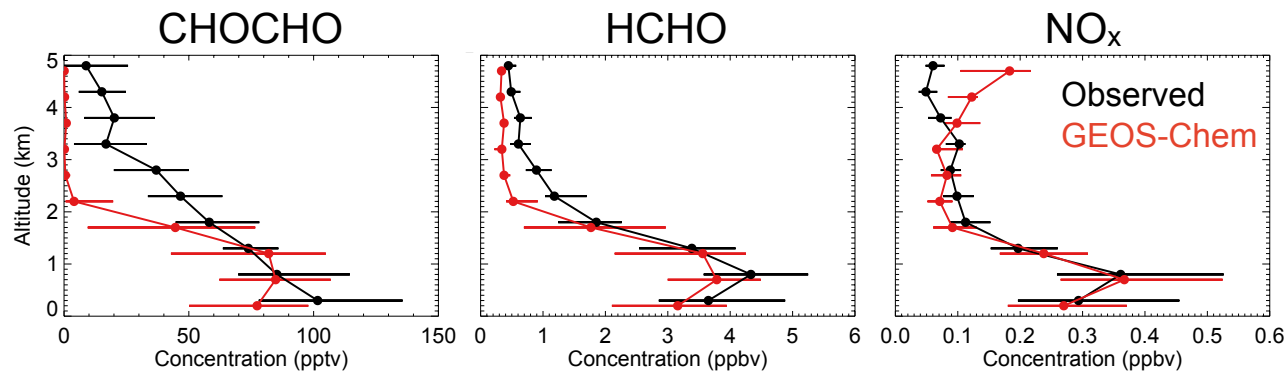

Figure 3. Median vertical profiles of $\mathrm{CHOCHO}, \mathrm{HCHO}$, and $\mathrm{NO}_{x}$ concentrations during SENEX (1 June-10 July 2013). Observed concentrations (Min et al., 2016; Cazorla et al., 2015; Pollack et al., 2010) are compared to GEOS-Chem model values sampled along the flight tracks. Horizontal bars indicate interquartile range. Altitudes are above ground level (a.g.1.).

Spectrometer (ACES; Min et al., 2016), In Situ Airborne Formaldehyde (ISAF) instrument (Cazorla et al., 2015), and the NOAA chemiluminescence instrument (Ryerson et al., 1999; Pollack et al., 2010), with stated accuracies of 6, 10, and $5 \%$, respectively.

Simulated median $\mathrm{NO}_{x}$ concentrations in the mixed layer are within $10 \%$ of observations, supporting the $50 \%$ reduction in EPA NEI NO$x$ emissions previously inferred from the analysis of SEAC ${ }^{4}$ RS observations by Travis et al. (2016), also included here (Sect. 2.1). Half of isoprene oxidation in the model under the SENEX conditions takes place by the low- $\mathrm{NO}_{x}$ pathways (Fig. 1). Simulated median $\mathrm{CHOCHO}$ and $\mathrm{HCHO}$ concentrations in the mixed layer are within $20 \%$ of observations, but the model is too low at higher altitudes. During SENEX the mixed layer was typically capped by a neutrally stable transition layer of shallow cumulus convection which extended up to $3 \mathrm{~km}$ (Wagner et al., 2015), which could suggest that the model underestimates transport via this mechanism. However, the model does not underestimate other isoprene oxidation products in the transition layer, such as MVK + methacrolein (Fig. S8 in the Supplement). Another possible source of $\mathrm{CHOCHO}$ in the transition layer is via heterogeneous aerosol oxidation (Volkamer et al., 2015). However, specific aerosol precursors that produce $\mathrm{CHOCHO}$ at yields required to match the SENEX observations are currently unknown (Kaiser et al., 2015).

The $\mathrm{CHOCHO}$ observations in the free troposphere $(>3 \mathrm{~km}$ ) have to be treated with caution since they are below the reported instrument precision ( 32 pptv, Kaiser et al., 2015). It is therefore difficult to determine whether the bias is due to a missing $\mathrm{CHOCHO}$ source in the model or instrument artifact. Elevated $\mathrm{CHOCHO}$ concentrations above the boundary layer have also been observed in previous campaigns over the southeast US (Lee et al., 1998), California (Baidar et al., 2013), and the remote Pacific (Volkamer et al., 2015). There could be a free-tropospheric source missing in the model, but it is unclear what this source could be, and correlative analysis of observed free-tropospheric $\mathrm{CHOCHO}$ with other species measured in SENEX offer no insight $(r<0.3$ for all observed VOCs).
The mixed layer concentrations maps in Fig. 4 show that the model captures some of the horizontal variability in the observations. The spatial correlation for $\mathrm{HCHO}$ is high $(r=0.75)$ as in $\mathrm{SEAC}^{4} \mathrm{RS}(r=0.64$, Zhu et al., 2016), and reflects isoprene emission patterns. Correlation for CHO$\mathrm{CHO}$ is also relatively strong $(r=0.51)$. Temporally averaged $\mathrm{CHOCHO}$ and $\mathrm{HCHO}$ concentrations simulated by the model for the SENEX period (background in Fig. 4) are much more uniform than those sampled along the SENEX flight tracks because of day-to-day variability in isoprene emissions, mostly driven by temperature (Zhu et al., 2016).

Figure 5 compares simulated and observed $\mathrm{CHOCHO}$ vs. $\mathrm{HCHO}$ relationships in the mixed layer, color coded by $\mathrm{NO}_{x}$ concentrations. Correlation between the two species is strong. The model better captures the observed slope ( 0.028 modeled vs. 0.024 observed) compared to the AM3 CTM (0.045 and 0.035 with and without $\mathrm{CHOCHO}$ production from $\delta$-ISOPO ${ }_{2}+\mathrm{NO}$, respectively; Li et al., 2016). Inclusion of aerosol uptake further reduces the bias to the observed slope (0.026, Fig. S10). On average, $\mathrm{CHOCHO}$ is produced more promptly in AM3 compared to GEOS-Chem, which may lead to the higher slope. In the first few hours of oxidation this is due to a higher $\mathrm{CHOCHO}$ yield from $\mathrm{ISOPO}_{2}$ isomerization. Beyond the initial stages of isoprene oxidation, $\mathrm{CHOCHO}$ is produced faster in AM3 because of the increased fraction of $\mathrm{CHOCHO}$ produced from IEPOX over GLYC oxidation (Fig. 1).

The strong correlation between $\mathrm{CHOCHO}$ and $\mathrm{HCHO}$ might suggest that they provide redundant information for constraining isoprene emissions. However, examination of Fig. 5 indicates higher observed $\mathrm{CHOCHO}-$ to-HCHO ratios $\left(R_{\mathrm{GF}}\right)$ at low- $\mathrm{NO}_{x}$ concentrations, not captured by GEOSChem. Figure 6 shows the $R_{\mathrm{GF}}$ ratio as a function of $\mathrm{NO}_{x}$ below $1 \mathrm{~km}$ in the SENEX observations and as simulated by GEOS-Chem. Points are color coded by OH exposure time $t_{\mathrm{OH}}$ (Eq. 1), derived from PTR-MS observations of the methylvinylketone + methacrolein-to-isoprene ratio (de Gouw and Warneke, 2007) following Wolfe et al. (2016). The median and interquartile $R_{\mathrm{GF}}$ values binned in 250 pptv $\mathrm{NO}_{x}$ increments are also shown. The observed me- 


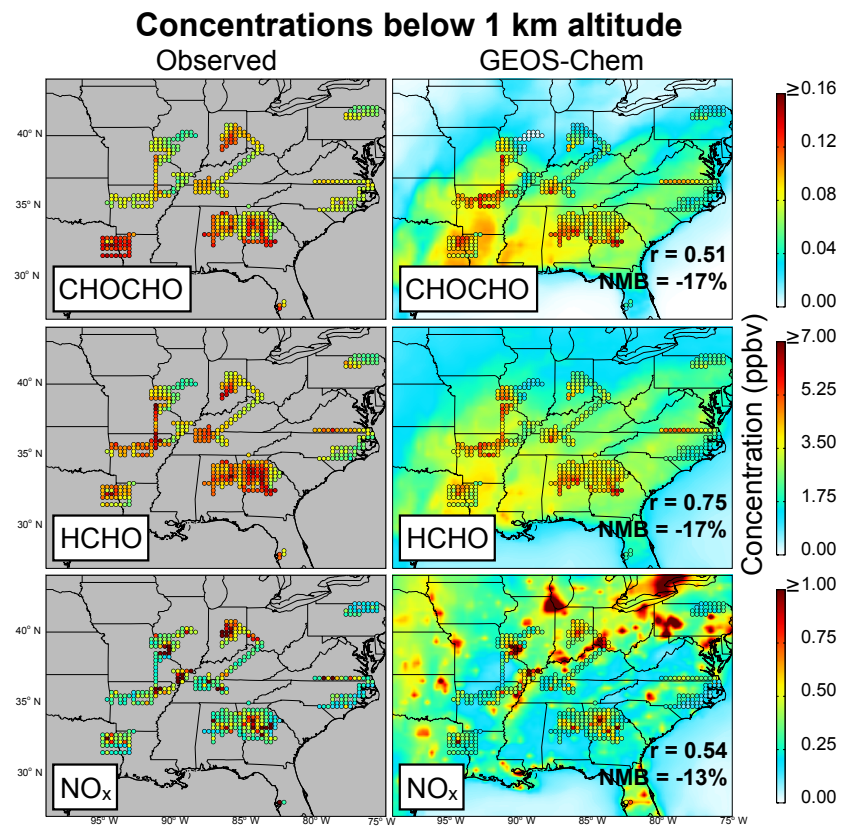

Figure 4. $\mathrm{CHOCHO}, \mathrm{HCHO}$, and $\mathrm{NO}_{x}$ concentrations below $1 \mathrm{~km}$ a.g.l. during SENEX (1 June-10 July 2013). The grid squares show daytime aircraft observations compared to the colocated GEOS-Chem model values on the $0.25^{\circ} \times 0.3125^{\circ}$ model grid. Background contours in the right panels show the average modelsimulated concentrations at 13:00-14:00 LT for the SENEX period. Comparison statistics between model and observation grid squares are shown as the correlation coefficient $r$ and the normalized mean bias (NMB). Correlation statistics for $\mathrm{NO}_{2}$ exclude urban plumes in the observations $\left(\left[\mathrm{NO}_{x}\right]>4 \mathrm{ppb}\right)$ as these would not be resolved at the scale of the model.

dian $R_{\mathrm{GF}}$ values ( 0.02 to $0.024 \mathrm{~mol} \mathrm{~mol}^{-1}$ ) show no significant dependence on $\mathrm{NO}_{x}$, while GEOS-Chem shows a weak dependence.

The observations contain a subset of low- $\mathrm{NO}_{x}$ points with higher $R_{\mathrm{GF}}$ values $(0.03-0.06)$. The model also produces a subset of enhanced $R_{\mathrm{GF}}$ values under low-NO $\mathrm{NO}_{x}$ conditions, although peak $R_{\mathrm{GF}}$ values are lower than the observations. In both cases, the enhanced $R_{\mathrm{GF}}$ values coincide with short $\mathrm{OH}$ exposure times, which are caused by $\mathrm{OH}$ titration by isoprene. The high $R_{\mathrm{GF}}$ reflects the relatively faster production of CHOCHO than HCHO in the early stage of isoprene oxidation under low- $\mathrm{NO}_{x}$ conditions as shown by Fig. 2. The presence of that population in the observations provides support for fast glyoxal production from the isomerization pathway of isoprene oxidation (Fig. 1) that is present in GEOSChem but not in MCMv3.3.1. The model may not capture the highest observed $R_{\mathrm{GF}}$ values due to uncertainties in the yield of DHDC from isoprene and its photolysis rate, both of which have been estimated based on literature proxies (Sect. S3).

Figure 6 also shows that there is a small subset of points in GEOS-Chem with RGF values less than 0.01, reflecting low $\mathrm{CHOCHO}$ values in the model that are not found in the observations where the concentration floor is $0.05 \mathrm{ppbv}$ (Fig. 5). There may be a $\mathrm{CHOCHO}$ background missing from the model, possibly contributed by monoterpenes; MCMv3.3.1 predicts that the total CHOCHO yield from common monoterpenes is high (Kaiser et al., 2015), and that they produce $\mathrm{CHOCHO}$ over a timescale of days (Fig. S11).

\section{Implications for satellite observations}

Knowledge gained from SENEX enables an improved interpretation of $\mathrm{CHOCHO}$ and $\mathrm{HCHO}$ column observations from space in isoprene dominated environments. We use for this purpose June-August in 2006 and 2007 observations of $\mathrm{CHOCHO}, \mathrm{HCHO}$, and tropospheric $\mathrm{NO}_{2}$ columns from the Ozone Monitoring Instrument (OMI). OMI was launched onboard the NASA Aura satellite in July 2004, and provides daily global coverage in sun-synchronous orbit with an equatorial crossing time of 13:40 LT. The CHOCHO data are from the Smithsonian Astrophysical Observatory (SAO) retrieval described in Chan Miller et al. (2014) and hereby referred to as OMI SAO. The $\mathrm{HCHO}$ and $\mathrm{NO}_{2}$ data are from the OMI Version 3 product release (González Abad et al., 2015; Bucsela et al., 2013). Retrievals are in the $435-461 \mathrm{~nm}$ spectral range for CHOCHO, 328.5-356.5 nm for HCHO, and 405$465 \mathrm{~nm}$ for $\mathrm{NO}_{2}$. We use 2006-2007 data because 2013 data for CHOCHO are very noisy (Fig. S12), possibly because of sensor degradation. The OMI observations are compared to a GEOS-Chem simulation covering the same period, at $2^{\circ} \times 2.5^{\circ}$ horizontal resolution.

Slant columns along the optical path of the backscattered solar radiation are fitted to the observed spectra and converted to vertical columns by division with an air mass factor (AMF) that accounts for the viewing geometry, atmospheric scattering, and the vertical profile of the gas (Palmer et al., 2001):

$\mathrm{AMF}=\int_{0}^{\infty} w(z) s(z) \mathrm{d} z$.

Here $w(z)$ is the scattering weight measuring the sensitivity of the retrieval to the gas concentration at altitude $z$, and $s(z)$ is a normalized vertical profile of gas number density. Here we recomputed the AMFs for the three retrievals using vertical profiles from GEOS-Chem, as it is necessary for comparing simulated and observed vertical columns (Duncan et al., 2014).

We remove observations impacted by the row anomaly (http://www.knmi.nl/omi/research/product/ rowanomaly-background.php), and those with cloud fractions over $20 \%$. Previous validation of the OMI HCHO retrievals with SEAC ${ }^{4} \mathrm{RS}$ aircraft observations revealed a 

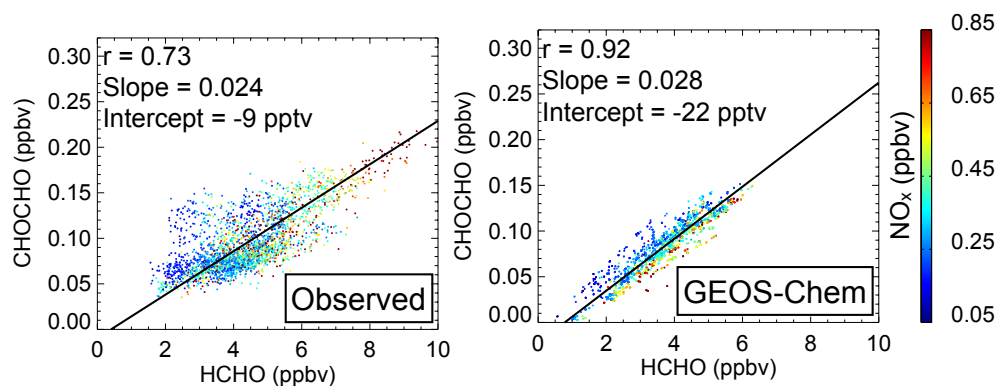

Figure 5. Relationship between $\mathrm{CHOCHO}$ and $\mathrm{HCHO}$ concentrations in the mixed layer ( $<1 \mathrm{kma.g} .1$.) during SENEX (1 June10 July 2013), color coded by $\mathrm{NO}_{x}$ concentration. Observed concentrations (Min et al., 2016; Cazorla et al., 2015) are compared to GEOSChem model values sampled along the flight tracks. Lines and reported slopes are from reduced major axis regressions.
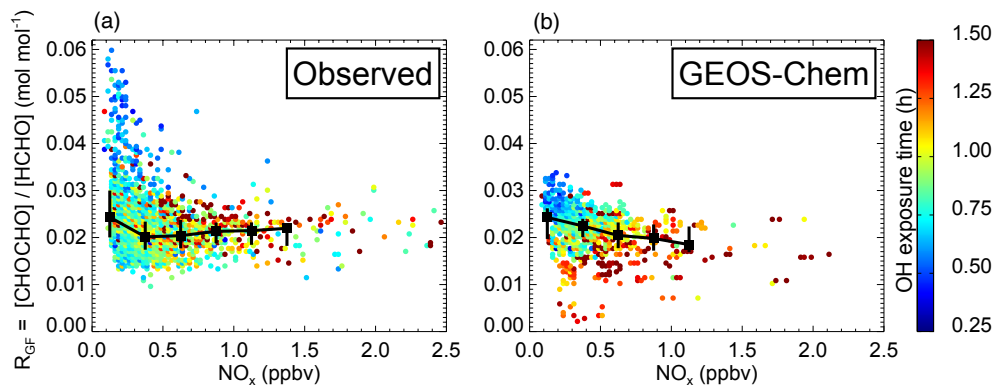

Figure 6. Dependence of the CHOCHO-to-HCHO ratio $R_{\mathrm{GF}}$ on $\mathrm{NO}_{x}$ concentrations for the SENEX conditions. Observations below $1 \mathrm{~km}$ altitude (a) are compared to GEOS-Chem model values sampled along the flight tracks (b). Points are color coded by the OH exposure time $t_{\mathrm{OH}}$ (Eq. 1). Binned median and interquartile $R_{\mathrm{GF}}$ values in increments of 250 pptv NO for bins with more than 20 values are also shown.

$43 \%$ uniform low bias (Zhu et al., 2016), corrected in the data shown here.

Figure 7 compares $\mathrm{CHOCHO}$ and $\mathrm{HCHO}$ vertical columns from GEOS-Chem and OMI, and Fig. 8 shows spatial correlations over the eastern US. Excellent agreement is found for $\mathrm{HCHO}$, providing an independent test of the correction to the OMI HCHO retrieval inferred from the SEAC ${ }^{4} \mathrm{RS}$ data (Zhu et al., 2016). Since GEOS-Chem can also replicate the CHOCHO-HCHO correlation in the SENEX data, the simulated $\mathrm{CHOCHO}$ columns can be used to indirectly validate the OMI CHOCHO observations. CHOCHO from OMI is highly correlated with GEOS-Chem $(r=0.81)$, indicative of the isoprene source. However OMI CHOCHO shows a higher continental background and a factor of 2 weaker enhancement over the southeast US.

Zhu et al. (2016) suggested that errors in the assumed surface reflectivities affecting the AMFs were an important source of the bias in the OMI HCHO retrievals. CHOCHO retrievals are even more sensitive to surface reflectivity because of the longer wavelengths. Russell et al. (2011) previously pointed out that the OMI surface reflectivities used in the standard $\mathrm{NO}_{2}$ retrievals (Kleipool et al., 2008) were too high and replaced them with high-resolution $\left(0.05^{\circ} \times 0.05^{\circ}\right)$ reflectivity observations from MODIS (Schaaf and Wang, 2015) to produce the Berkeley High-Resolution (BEHR) OMI $\mathrm{NO}_{2}$ retrieval. $\mathrm{CHOCHO}$ and $\mathrm{NO}_{2}$ are retrieved at similar wavelengths so the sensitivity to surface reflectivity should be similar. Figure 7 (bottom right) shows the mean $\mathrm{CHOCHO}$ scattering weights computed from the OMI-SAO and BEHR. The lower BEHR surface reflectivity values result in a lower AMF and hence a higher vertical column (Fig. 7, bottom left panel). The slope of the regression between GEOS-Chem and OMI CHOCHO columns increases from 0.48 to 0.62 , improving but not reconciling the differences.

As pointed out above, SENEX and other observations suggest that GEOS-Chem may be missing a background source of CHOCHO. Integration of the median $\mathrm{CHOCHO}$ profile above $2 \mathrm{~km}$ in Fig. 3 shows a negative model bias of $1.3 \times 10^{14}$ molecules $\mathrm{cm}^{-2}$, comparable to the continental background intercept in Fig. $8\left(1.9 \times 10^{14}\right.$ molecules $\left.\mathrm{cm}^{-2}\right)$. The nonzero intercept may in part reflect an underestimate of $\mathrm{CHOCHO}$ concentrations caused by a missing $\mathrm{CHOCHO}$ source over the southeast US, such as monoterpenes (Sect. 3). The presence of free-tropospheric CHOCHO would further impact the AMF calculation under continental background conditions since the retrieval sensitivity as measured by the scattering weights increases with altitude. Thus the retrieved continental background would be overestimated.

Figure 9 shows $\mathrm{CHOCHO}$ vs. $\mathrm{HCHO}$ relationships for OMI (using the BEHR scattering weights) and GEOS-Chem, 


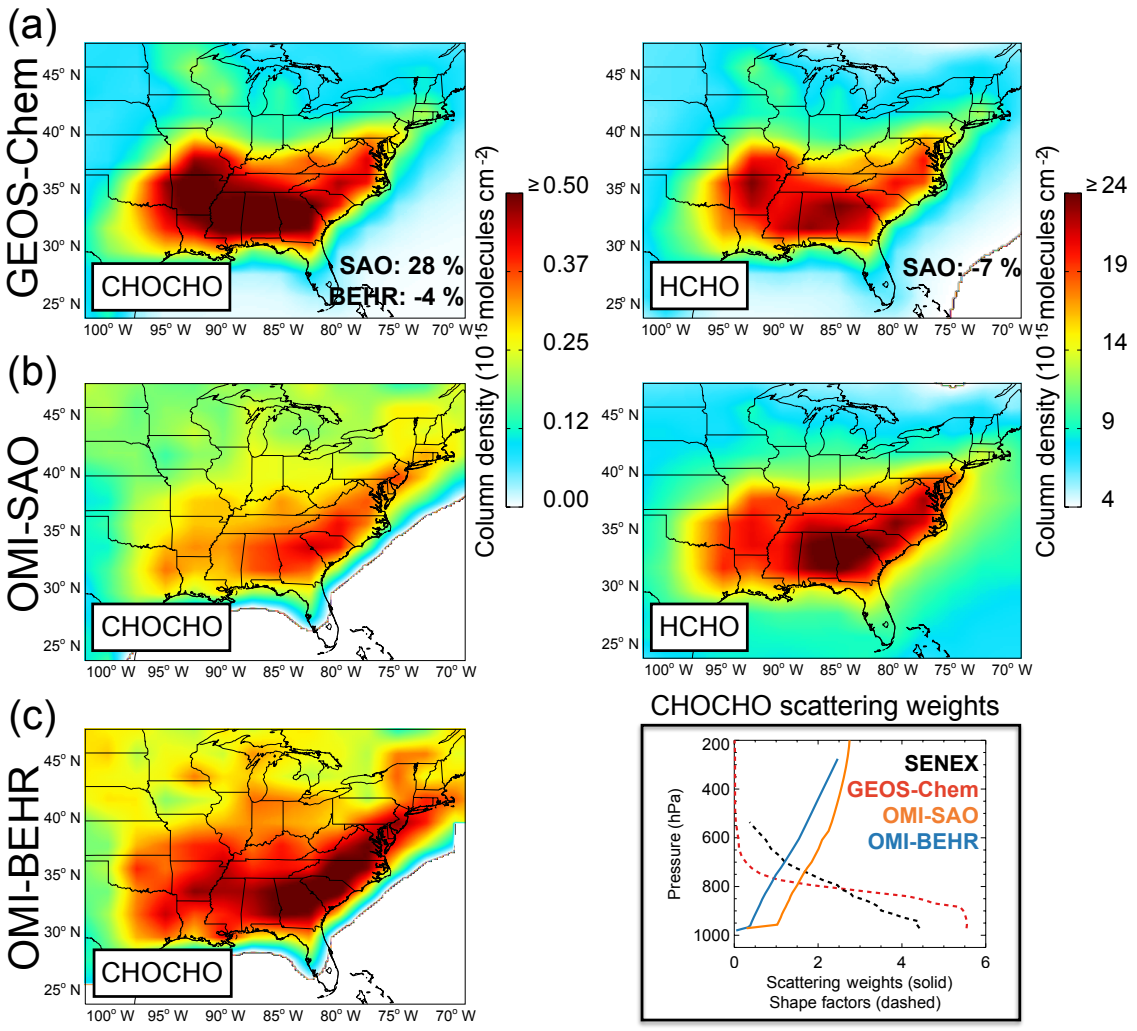

Figure 7. Mean CHOCHO and HCHO columns in summer (JJA) 2006-2007. GEOS-Chem model values (a) are compared to OMI satellite observations (b, c). OMI-SAO is the standard operational product (Chan Miller et al., 2014; González Abad et al., 2015). The OMI-BEHR product for $\mathrm{CHOCHO}$ uses tropospheric scattering weights from the $\mathrm{BEHR} \mathrm{NO}_{2}$ retrieval (Russell et al., 2011; Laughner et al., 2016). The OMI HCHO observations have been scaled up by a factor of 1.67 to correct for retrieval bias (Zhu et al., 2016). The normalized mean bias (NMB) between GEOS-Chem and OMI in the southeast US $\left(75-100^{\circ} \mathrm{W}, 29.5-37.5^{\circ} \mathrm{N}\right)$ is shown within the GEOS-Chem panels. The right panel of (c) shows the mean CHOCHO scattering weights $(w)$ from the OMI-SAO and OMI-BEHR retrievals and the vertical shape factors $(s)$ over the southeast US from the SENEX observations and GEOS-Chem in the southeast US from a typical orbit (10114, 9 June 2006).
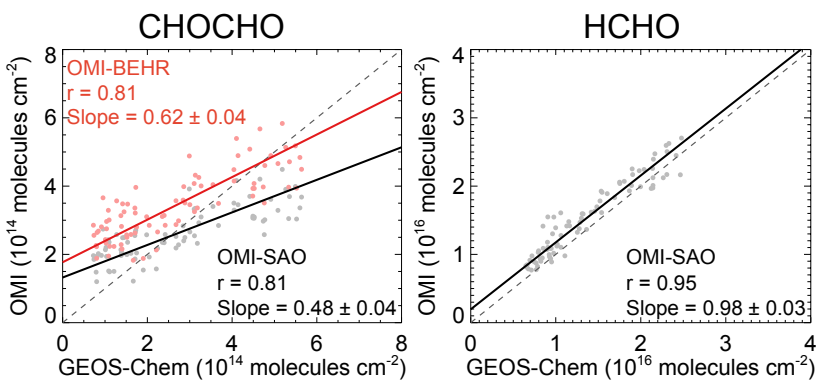

Figure 8. Scatterplots of OMI vs. GEOS-Chem $\mathrm{CHOCHO}$ and HCHO columns over the eastern US $\left(75-100^{\circ} \mathrm{W}, 29.5-45^{\circ} \mathrm{N}\right)$. Values are seasonal means for JJA 2006-2007 as plotted in Fig. 7. OMI observations for $\mathrm{CHOCHO}$ are from the standard SAO retrieval (Chan Miller et al., 2014) and using BEHR scattering weights (Russell et al., 2011; Laughner et al., 2016). Correlation coefficients and reduced-major-axis (RMA) regressions are shown. color coded by tropospheric $\mathrm{NO}_{2}$ columns. Individual points are seasonal averages (data points from Fig. 7) in order to limit noise. The slope is steeper in GEOS-Chem because the CHOCHO columns are higher. Since GEOS-Chem reproduces the aircraft $\mathrm{CHOCHO}-\mathrm{HCHO}$ relationship without bias (Fig. 5), this is further evidence of bias in the OMI CHOCHO observations. The CHOCHO-HCHO relationship is tight in both OMI $(r=0.86)$ and GEOS-Chem $(r=0.99)$, with no indication of a separate population of low-NO $\mathrm{NO}_{x}$ points with high $R_{\mathrm{GF}}$ as there was in the SENEX data. It thus appears from the OMI data that satellite observations of $\mathrm{CHOCHO}$ and $\mathrm{HCHO}$ in isoprene-dominated environments are redundant. This may reflect the higher $\mathrm{NO}_{x}$ levels in 2006-2007 compared to 2013 (Russell et al., 2012). However since median $R_{\mathrm{GF}}$ shows no significant variation with $\mathrm{NO}_{x}$ in the SENEX data (Fig. 6), the required temporal averaging of satellite observations is a more likely explanation for the tight correlation. Finer-scale and more temporally resolved data, as will be available from the TEMPO geostationary instrument to be launched in the 2018-2020 time 
Relationship between $\mathrm{CHOCHO}$ and $\mathrm{HCHO}$ columns
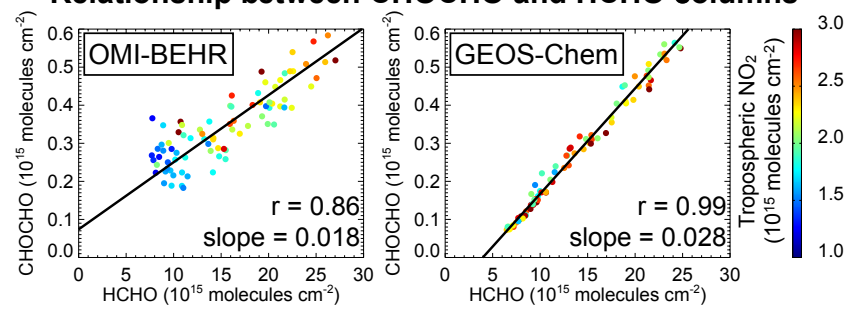

Figure 9. Relationship between $\mathrm{CHOCHO}$ and $\mathrm{HCHO}$ vertical columns over the eastern US $\left(75-100^{\circ} \mathrm{W}, 29.5-45^{\circ} \mathrm{N}\right)$ in JuneAugust 2006 and 2007 color coded by tropospheric $\mathrm{NO}_{2}$ columns. OMI values with $\mathrm{CHOCHO}$ AMFs computed from BEHR scattering weights are compared to GEOS-Chem values. Lines and reported slopes are from reduced major axis regressions.

frame (Zoogman et al., 2016), may provide new perspectives of the utility of the $\mathrm{CHOCHO}$ retrieval.

\section{Conclusions}

We have used aircraft observations of glyoxal (CHOCHO), formaldehyde (HCHO), and related species from the SENEX aircraft campaign over the southeast US together with OMI satellite data to better understand the $\mathrm{CHOCHO}$ yield from isoprene and the complementarity of $\mathrm{CHOCHO}$ and $\mathrm{HCHO}$ observations from space for constraining isoprene emissions. This work includes a first validation of the $\mathrm{CHOCHO}$ retrieval from the OMI satellite instrument.

We began with an analysis of the time- and $\mathrm{NO}_{x}$ dependent $\mathrm{CHOCHO}$ and $\mathrm{HCHO}$ yields from isoprene oxidation in the GEOS-Chem chemical transport model and in the Master Chemical Mechanism (MCMv3.3.1). The GEOSChem mechanism features several updates relevant to $\mathrm{CHO}-$ $\mathrm{CHO}$ formation. These include a decrease in the $\delta-\mathrm{ISOPO}_{2}+$ $\mathrm{NO}$ branching ratio leading to prompt $\mathrm{CHOCHO}$ production under high- $\mathrm{NO}_{x}$ conditions, and a proposed low- $\mathrm{NO}_{x}$ pathway for prompt $\mathrm{CHOCHO}$ formation by photolysis of a dihydroperoxide dicarbonyl compound (DHDC) product from $(1,5) \mathrm{H}$-shift isomerization of dihydroperoxy $\alpha$-formyl peroxy radicals in the $\mathrm{ISOPO}_{2}$ isomerization pathway (Fig. 1). GEOS-Chem and MCMv3.3.1 show similar HCHO yields from isoprene, increasing with increasing $\mathrm{NO}_{x}$. $\mathrm{CHOCHO}$ yields from isoprene in MCMv3.3.1 show behavior similar to $\mathrm{HCHO}$ but GEOS-Chem has a higher yield at low $\mathrm{NO}_{x}$ from the $\mathrm{ISOPO}_{2}$ isomerization pathway.

Comparison of GEOS-Chem to the SENEX observations of $\mathrm{CHOCHO}$ and $\mathrm{HCHO}$ shows good agreement in the boundary layer but a negative $\mathrm{CHOCHO}$ model bias in the free troposphere. This could reflect an instrument artifact but may also imply a missing background source in the model. Mixed layer $(<1 \mathrm{~km})$ observations show a strong CHOCHO-HCHO relationship that is reproduced in GEOSChem and is remarkably consistent across all conditions ex- cept at very low $\mathrm{NO}_{x}$ where the $[\mathrm{CHOCHO}] /[\mathrm{HCHO}]$ ratio $\left(R_{\mathrm{GF}}\right)$ can be unusually high. This reflects prompt formation of $\mathrm{CHOCHO}$ under low- $\mathrm{NO}_{x}$ conditions, which was missing from MCMv3.3.1 and is now simulated in our updated GEOS-Chem mechanism by DHDC photolysis. A previous model comparison to SENEX showed that MCMv3.3.1 underestimates the $\mathrm{CHOCHO}$ yield from isoprene ( $\mathrm{Li}$ et al., 2016). Our work shows the missing DHDC production pathway can explain approximately $60 \%$ of this underestimate, with the remainder caused by an underestimate of the $\delta$ $\mathrm{ISOPO}_{2}$ branching ratio (3.4\% in MCMv3.3.1 vs. $10 \%$ in GEOS-Chem).

The SENEX observations enable indirect validation of the OMI CHOCHO satellite data using GEOS-Chem as an intercomparison platform. The OMI data show a continental background that is consistent with the SENEX freetropospheric observations, and an enhancement over the southeast US that is consistent with the isoprene source. However this enhancement is a factor of 2 too low in the OMI data. A partial explanation is that surface reflectivities assumed in the standard OMI retrieval are too high. The satellite data show strong $\mathrm{CHOCHO}-\mathrm{HCHO}$ correlation consistent with the model and imply that the two gases provide redundant information for constraining isoprene emissions in regions where isoprene is their dominant precursor. This redundancy may reflect the seasonal averaging in the OMI data required to reduce noise. Recent validation of the $\mathrm{HCHO}$ satellite data revealed negative retrieval biases (Zhu et al., 2016), which can be corrected using spatially uniform scaling factors (as done in this study). Since similar biases may exist for the $\mathrm{CHOCHO}$ retrieval, the scaled $\mathrm{HCHO}$ data should at present be preferentially used as proxy for isoprene emissions. Future geostationary observations from TEMPO (Zoogman et al., 2016) will require less temporal averaging and this may reveal the utility of $\mathrm{CHOCHO}$ observations for estimating isoprene emissions under low- $\mathrm{NO}_{x}$ conditions when isoprene oxidation is titrated.

Data availability. The SENEX observations used in this paper are publicly accessible online (https://esrl.noaa.gov/csd/groups/csd7/ measurements/2013senex/). OMI CHOCHO, $\mathrm{HCHO}$ and $\mathrm{NO}_{2}$ observations can be obtained from the Aura Validation Data Center (https://avdc.gsfc.nasa.gov/). Details on how to download GEOSChem source code can be found at http://www.geos-chem.org.

Competing interests. The authors declare that they have no conflict of interest.

The Supplement related to this article is available online at https://doi.org/10.5194/acp-17-8725-2017-supplement. 
Acknowledgements. This work was funded by NASA ACMAP and ACCDAM and is a contribution to the NASA Aura Science Team. This research was undertaken with the assistance of resources provided at the NCI National Facility systems at the Australian National University through the National Computational Merit Allocation Scheme supported by the Australian Government. Jennifer Kaiser, Frank N. Keutsch, Glenn M. Wolfe, and Thomas F. Hanisco acknowledge support from the US EPA Science to Achieve Results (STAR) program (grant 83540601).

Edited by: Nga Lee $\mathrm{Ng}$

Reviewed by: three anonymous referees

\section{References}

Abbot, D. S., Palmer, P. I., Martin, R. V., Chance, K. V., Jacob, D. J., and Guenther, A.: Seasonal and interannual variability of North American isoprene emissions as determined by formaldehyde column measurements from space, Geophys. Res. Lett., 30, 1886, https://doi.org/10.1029/2003GL017336, 2003.

Alvarado, L. M. A., Richter, A., Vrekoussis, M., Wittrock, F., Hilboll, A., Schreier, S. F., and Burrows, J. P.: An improved glyoxal retrieval from OMI measurements, Atmos. Meas. Tech., 7, 4133-4150, https://doi.org/10.5194/amt-7-4133-2014, 2014.

Baidar, S., Oetjen, H., Coburn, S., Dix, B., Ortega, I., Sinreich, R., and Volkamer, R.: The CU Airborne MAX-DOAS instrument: vertical profiling of aerosol extinction and trace gases, Atmos. Meas. Tech., 6, 719-739, https://doi.org/10.5194/amt-6719-2013, 2013

Barkley, M. P., De Smedt, I., Van Roozendael, M., Kurosu, T. P., Chance, K., Arneth, A., Hagberg, D., Guenther, A., Paulot, F., Marais, E., and Mao, J.: Top-down isoprene emissions over tropical South America inferred from SCIAMACHY and OMI formaldehyde columns, J. Geophys. Res.-Atmos., 118, 68496868, https://doi.org/10.1002/jgrd.50552, 2013.

Bates, K. H., Crounse, J. D., Clair, J. M. S., Bennett, N. B., Nguyen, T. B., Seinfeld, J. H., Stoltz, B. M., and Wennberg, P. O.: Gas Phase Production and Loss of Isoprene Epoxydiols, J. Phys. Chem. A, 118, 1237-1246, https://doi.org/10.1021/jp4107958, 2014.

Browne, E. C. and Cohen, R. C.: Effects of biogenic nitrate chemistry on the $\mathrm{NO}_{x}$ lifetime in remote continental regions, Atmos. Chem. Phys., 12, 11917-11932, https://doi.org/10.5194/acp-1211917-2012, 2012.

Bucsela, E. J., Krotkov, N. A., Celarier, E. A., Lamsal, L. N., Swartz, W. H., Bhartia, P. K., Boersma, K. F., Veefkind, J. P., Gleason, J. F., and Pickering, K. E.: A new stratospheric and tropospheric $\mathrm{NO}_{2}$ retrieval algorithm for nadir-viewing satellite instruments: applications to OMI, Atmos. Meas. Tech., 6, 26072626, https://doi.org/10.5194/amt-6-2607-2013, 2013.

Carlton, A. G., Wiedinmyer, C., and Kroll, J. H.: A review of Secondary Organic Aerosol (SOA) formation from isoprene, Atmos. Chem. Phys., 9, 4987-5005, https://doi.org/10.5194/acp-9-49872009, 2009.

Cazorla, M., Wolfe, G. M., Bailey, S. A., Swanson, A. K., Arkinson, H. L., and Hanisco, T. F.: A new airborne laser-induced fluorescence instrument for in situ detection of formaldehyde through- out the troposphere and lower stratosphere, Atmos. Meas. Tech., 8, 541-552, https://doi.org/10.5194/amt-8-541-2015, 2015.

Chance, K., Palmer, P. I., Spurr, R. J. D., Martin, R. V., Kurosu, T. P., and Jacob, D. J.: Satellite observations of formaldehyde over North America from GOME, Geophys. Res. Lett., 27, 34613464, https://doi.org/10.1029/2000GL011857, 2000.

Chan Miller, C., Gonzalez Abad, G., Wang, H., Liu, X., Kurosu, T., Jacob, D. J., and Chance, K.: Glyoxal retrieval from the Ozone Monitoring Instrument, Atmos. Meas. Tech., 7, 38913907, https://doi.org/10.5194/amt-7-3891-2014, 2014.

Chan Miller, C., Jacob, D. J., González Abad, G., and Chance, K.: Hotspot of glyoxal over the Pearl River delta seen from the OMI satellite instrument: implications for emissions of aromatic hydrocarbons, Atmos. Chem. Phys., 16, 4631-4639, https://doi.org/10.5194/acp-16-4631-2016, 2016.

Crounse, J. D., Paulot, F., Kjaergaard, H. G., and Wennberg, P. O.: Peroxy radical isomerization in the oxidation of isoprene, Phys. Chem. Chem. Phys., 13, 13607-13613, https://doi.org/10.1039/C1CP21330J, 2011.

Crounse, J. D., Nielsen, L. B., Jørgensen, S., Kjaergaard, H. G., and Wennberg, P. O.: Autoxidation of Organic Compounds in the Atmosphere, The J. Phys. Chem. Lett., 4, 3513-3520, https://doi.org/10.1021/jz4019207, 2013.

Curci, G., Palmer, P. I., Kurosu, T. P., Chance, K., and Visconti, G.: Estimating European volatile organic compound emissions using satellite observations of formaldehyde from the Ozone Monitoring Instrument, Atmos. Chem. Phys., 10, 11501-11517, https://doi.org/10.5194/acp-10-11501-2010, 2010.

de Gouw, J. and Warneke, C.: Measurements of volatile organic compounds in the earth's atmosphere using proton-transferreaction mass spectrometry, Mass Spectrom. Rev., 26, 223-257, https://doi.org/10.1002/mas.20119, 2007.

DiGangi, J. P., Henry, S. B., Kammrath, A., Boyle, E. S., Kaser, L., Schnitzhofer, R., Graus, M., Turnipseed, A., Park, J.-H., Weber, R. J., Hornbrook, R. S., Cantrell, C. A., Maudlin III, R. L., Kim, S., Nakashima, Y., Wolfe, G. M., Kajii, Y., Apel, E. C., Goldstein, A. H., Guenther, A., Karl, T., Hansel, A., and Keutsch, F. N.: Observations of glyoxal and formaldehyde as metrics for the anthropogenic impact on rural photochemistry, Atmos. Chem. Phys., 12, 9529-9543, https://doi.org/10.5194/acp-129529-2012, 2012.

Duncan, B. N., Prados, A. I., Lamsal, L. N., Liu, Y., Streets, D. G., Gupta, P., Hilsenrath, E., Kahn, R. A., Nielsen, J. E., Beyersdorf, A. J., Burton, S. P., Fiore, A. M., Fishman, J., Henze, D. K., Hostetler, C. A., Krotkov, N. A., Lee, P., Lin, M., Pawson, S., Pfister, G., Pickering, K. E., Pierce, R. B., Yoshida, Y., and Ziemba, L. D.: Satellite data of atmospheric pollution for U.S. air quality applications: Examples of applications, summary of data end-user resources, answers to FAQs, and common mistakes to avoid, Atmos. Environ., 94, 647-662, https://doi.org/10.1016/j.atmosenv.2014.05.061, 2014.

Emmerson, K. M. and Evans, M. J.: Comparison of tropospheric gas-phase chemistry schemes for use within global models, Atmos. Chem. Phys., 9, 1831-1845, https://doi.org/10.5194/acp-91831-2009, 2009.

Fisher, J. A., Jacob, D. J., Travis, K. R., Kim, P. S., Marais, E. A., Chan Miller, C., Yu, K., Zhu, L., Yantosca, R. M., Sulprizio, M. P., Mao, J., Wennberg, P. O., Crounse, J. D., Teng, A. P., Nguyen, T. B., St. Clair, J. M., Cohen, R. C., Romer, 
P., Nault, B. A., Wooldridge, P. J., Jimenez, J. L., CampuzanoJost, P., Day, D. A., Hu, W., Shepson, P. B., Xiong, F., Blake, D. R., Goldstein, A. H., Misztal, P. K., Hanisco, T. F., Wolfe, G. M., Ryerson, T. B., Wisthaler, A., and Mikoviny, T.: Organic nitrate chemistry and its implications for nitrogen budgets in an isoprene- and monoterpene-rich atmosphere: constraints from aircraft (SEAC $\left.{ }^{4} \mathrm{RS}\right)$ and ground-based (SOAS) observations in the Southeast US, Atmos. Chem. Phys., 16, 5969-5991, https://doi.org/10.5194/acp-16-5969-2016, 2016.

Fortems-Cheiney, A., Chevallier, F., Pison, I., Bousquet, P., Saunois, M., Szopa, S., Cressot, C., Kurosu, T. P., Chance, K., and Fried, A.: The formaldehyde budget as seen by a globalscale multi-constraint and multi-species inversion system, Atmos. Chem. Phys., 12, 6699-6721, https://doi.org/10.5194/acp12-6699-2012, 2012

Fu, T.-M., Jacob, D. J., Palmer, P. I., Chance, K., Wang, Y. X., Barletta, B., Blake, D. R., Stanton, J. C., and Pilling, M. J.: Space-based formaldehyde measurements as constraints on volatile organic compound emissions in east and south Asia and implications for ozone, J. Geophys. Res., 112, D06312, https://doi.org/10.1029/2006JD007853, 2007.

Fu, T.-M., Jacob, D. J., Wittrock, F., Burrows, J. P., Vrekoussis, M., and Henze, D. K.: Global budgets of atmospheric glyoxal and methylglyoxal, and implications for formation of secondary organic aerosols, J. Geophys. Res., 113, D15303, https://doi.org/10.1029/2007JD009505, 2008.

Galloway, M. M., Huisman, A. J., Yee, L. D., Chan, A. W. H., Loza, C. L., Seinfeld, J. H., and Keutsch, F. N.: Yields of oxidized volatile organic compounds during the $\mathrm{OH}$ radical initiated oxidation of isoprene, methyl vinyl ketone, and methacrolein under high-NO $\mathrm{NO}_{x}$ conditions, Atmos. Chem. Phys., 11, 10779-10790, https://doi.org/10.5194/acp-11-10779-2011, 2011.

Geng, F., Tie, X., Guenther, A., Li, G., Cao, J., and Harley, P.: Effect of isoprene emissions from major forests on ozone formation in the city of Shanghai, China, Atmos. Chem. Phys., 11, 1044910459, https://doi.org/10.5194/acp-11-10449-2011, 2011.

González Abad, G., Liu, X., Chance, K., Wang, H., Kurosu, T. P., and Suleiman, R.: Updated Smithsonian Astrophysical Observatory Ozone Monitoring Instrument (SAO OMI) formaldehyde retrieval, Atmos. Meas. Tech., 8, 19-32, https://doi.org/10.5194/amt-8-19-2015, 2015.

Guenther, A. B., Jiang, X., Heald, C. L., Sakulyanontvittaya, T., Duhl, T., Emmons, L. K., and Wang, X.: The Model of Emissions of Gases and Aerosols from Nature version 2.1 (MEGAN2.1): an extended and updated framework for modeling biogenic emissions, Geosci. Model Dev., 5, 1471-1492, https://doi.org/10.5194/gmd-5-1471-2012, 2012.

Jenkin, M. E., Young, J. C., and Rickard, A. R.: The MCM v3.3.1 degradation scheme for isoprene, Atmos. Chem. Phys., 15, 11433-11459, https://doi.org/10.5194/acp-15-11433-2015, 2015.

Kaiser, J., Wolfe, G. M., Min, K. E., Brown, S. S., Miller, C. C., Jacob, D. J., deGouw, J. A., Graus, M., Hanisco, T. F., Holloway, J., Peischl, J., Pollack, I. B., Ryerson, T. B., Warneke, C., Washenfelder, R. A., and Keutsch, F. N.: Reassessing the ratio of glyoxal to formaldehyde as an indicator of hydrocarbon precursor speciation, Atmos. Chem. Phys., 15, 7571-7583, https://doi.org/10.5194/acp-15-7571-2015, 2015.
Kim, P. S., Jacob, D. J., Fisher, J. A., Travis, K., Yu, K., Zhu, L., Yantosca, R. M., Sulprizio, M. P., Jimenez, J. L., CampuzanoJost, P., Froyd, K. D., Liao, J., Hair, J. W., Fenn, M. A., Butler, C. F., Wagner, N. L., Gordon, T. D., Welti, A., Wennberg, P. O., Crounse, J. D., St. Clair, J. M., Teng, A. P., Millet, D. B., Schwarz, J. P., Markovic, M. Z., and Perring, A. E.: Sources, seasonality, and trends of southeast US aerosol: an integrated analysis of surface, aircraft, and satellite observations with the GEOS-Chem chemical transport model, Atmos. Chem. Phys., 15, 10411-10433, https://doi.org/10.5194/acp-15-104112015, 2015.

Kleipool, Q. L., Dobber, M. R., de Haan, J. F., and Levelt, P. F.: Earth surface reflectance climatology from 3 years of OMI data, J. Geophys. Res.-Atmos., 113, D18308, https://doi.org/10.1029/2008JD010290, 008.

Laughner, J. L., Zare, A., and Cohen, R. C.: Effects of daily meteorology on the interpretation of space-based remote sensing of $\mathrm{NO}_{2}$, Atmos. Chem. Phys., 16, 15247-15264, https://doi.org/10.5194/acp-16-15247-2016, 2016.

Lee, Y.-N., Zhou, X., Kleinman, L. I., Nunnermacker, L. J., Springston, S. R., Daum, P. H., Newman, L., Keigley, W. G., Holdren, M. W., Spicer, C. W., Young, V., Fu, B., Parrish, D. D., Holloway, J., Williams, J., Roberts, J. M., Ryerson, T. B., and Fehsenfeld, F. C.: Atmospheric chemistry and distribution of formaldehyde and several multioxygenated carbonyl compounds during the 1995 Nashville/Middle Tennessee Ozone Study, J. Geophys. Res.-Atmos., 103, 22449-22462, https://doi.org/10.1029/98JD01251, 1998.

Li, J., Mao, J., Min, K.-E., Washenfelder, R. A., Brown, S. S., Kaiser, J., Keutsch, F. N., Volkamer, R., Wolfe, G. M., Hanisco, T. F., Pollack, I. B., Ryerson, T. B., Graus, M., Gilman, J. B., Lerner, B. M., Warneke, C., de Gouw, J. A., Middlebrook, A. M., Liao, J., Welti, A., Henderson, B. H., McNeill, V. F., Hall, S. R., Ullmann, K., Donner, L. J., Paulot, F., and Horowitz, L. W.: Observational constraints on glyoxal production from isoprene oxidation and its contribution to organic aerosol over the Southeast United States, J. Geophys. Res.-Atmos., 121, 9849-9861, https://doi.org/10.1002/2016JD025331, 2016.

Madronich, S.: Photodissociation in the atmosphere: 1. Actinic flux and the effects of ground reflections and clouds, J. Geophys. Res.-Atmos., 92, 9740-9752, https://doi.org/10.1029/JD092iD08p09740, 1987.

Mao, J., Paulot, F., Jacob, D. J., Cohen, R. C., Crounse, J. D., Wennberg, P. O., Keller, C. A., Hudman, R. C., Barkley, M. P., and Horowitz, L. W.: Ozone and organic nitrates over the eastern United States: Sensitivity to isoprene chemistry, J. Geophys. Res.-Atmos., 118, 11256-11268, https://doi.org/10.1002/jgrd.50817, 2013.

Marais, E. A., Jacob, D. J., Kurosu, T. P., Chance, K., Murphy, J. G., Reeves, C., Mills, G., Casadio, S., Millet, D. B., Barkley, M. P., Paulot, F., and Mao, J.: Isoprene emissions in Africa inferred from OMI observations of formaldehyde columns, Atmos. Chem. Phys., 12, 6219-6235, https://doi.org/10.5194/acp12-6219-2012, 2012.

Marais, E. A., Jacob, D. J., Jimenez, J. L., Campuzano-Jost, P., Day, D. A., Hu, W., Krechmer, J., Zhu, L., Kim, P. S., Miller, C. C., Fisher, J. A., Travis, K., Yu, K., Hanisco, T. F., Wolfe, G. M., Arkinson, H. L., Pye, H. O. T., Froyd, K. D., Liao, J., and McNeill, V. F.: Aqueous-phase mechanism for secondary or- 
ganic aerosol formation from isoprene: application to the southeast United States and co-benefit of $\mathrm{SO}_{2}$ emission controls, Atmos. Chem. Phys., 16, 1603-1618, https://doi.org/10.5194/acp16-1603-2016, 2016.

Millet, D. B., Jacob, D. J., Boersma, K. F., Fu, T.-M., Kurosu, T. P., Chance, K., Heald, C. L., and Guenther, A.: Spatial distribution of isoprene emissions from North America derived from formaldehyde column measurements by the OMI satellite sensor, J. Geophys. Res.-Atmos., 113, D02307, https://doi.org/10.1029/2007JD008950, 2008.

Min, K.-E., Washenfelder, R. A., Dubé, W. P., Langford, A. O., Edwards, P. M., Zarzana, K. J., Stutz, J., Lu, K., Rohrer, F., Zhang, Y., and Brown, S. S.: A broadband cavity enhanced absorption spectrometer for aircraft measurements of glyoxal, methylglyoxal, nitrous acid, nitrogen dioxide, and water vapor, Atmos. Meas. Tech., 9, 423-440, https://doi.org/10.5194/amt-9423-2016, 2016.

Molod, A., Takacs, L., Suarez, M., Bacmeister, J., Song, I.-S., and Eichmann, A.: The GEOS-5 Atmospheric General Circulation Model: Mean Climate and Development from MERRA to Fortuna, Tech. Rep. NASA/TM-2012-104606/Vol 28, Nasa Godard Space Flight Center, 2012.

Müller, J.-F., Peeters, J., and Stavrakou, T.: Fast photolysis of carbonyl nitrates from isoprene, Atmos. Chem. Phys., 14, 24972508, https://doi.org/10.5194/acp-14-2497-2014, 2014.

Palmer, P. I., Jacob, D. J., Chance, K., Martin, R. V., Spurr, R. J. D., Kurosu, T. P., Bey, I., Yantosca, R., Fiore, A., and Li, Q.: Air mass factor formulation for spectroscopic measurements from satellites: Application to formaldehyde retrievals from the Global Ozone Monitoring Experiment, J. Geophys. Res.-Atmos., 106, 14539-14550, https://doi.org/10.1029/2000JD900772, 2001.

Palmer, P. I., Jacob, D. J., Fiore, A. M., Martin, R. V., Chance, K., and Kurosu, T. P.: Mapping isoprene emissions over North America using formaldehyde column observations from space, J. Geophys. Res.-Atmos., 108, 4180, https://doi.org/10.1029/2002JD002153, 2003.

Palmer, P. I., Abbot, D. S., Fu, T.-M., Jacob, D. J., Chance, K., Kurosu, T. P., Guenther, A., Wiedinmyer, C., Stanton, J. C., Pilling, M. J., Pressley, S. N., Lamb, B., and Sumner, A. L.: Quantifying the seasonal and interannual variability of North American isoprene emissions using satellite observations of the formaldehyde column, J. Geophys. Res.-Atmos., 111, D12315, https://doi.org/10.1029/2005JD006689, 2006.

Paulot, F., Crounse, J. D., Kjaergaard, H. G., Kroll, J. H., Seinfeld, J. H., and Wennberg, P. O.: Isoprene photooxidation: new insights into the production of acids and organic nitrates, Atmos. Chem. Phys., 9, 1479-1501, https://doi.org/10.5194/acp-9-14792009, 2009a.

Paulot, F., Crounse, J. D., Kjaergaard, H. G., Kürten, A., St. Clair, J. M., Seinfeld, J. H., and Wennberg, P. O.: Unexpected Epoxide Formation in the Gas-Phase Photooxidation of Isoprene, Science, 325, 730-733, https://doi.org/10.1126/science.1172910, 2009b.

Peeters, J. and Muller, J.-F.: $\mathrm{HO}_{x}$ radical regeneration in isoprene oxidation via peroxy radical isomerisations. II: experimental evidence and global impact, Phys. Chem. Chem. Phys., 12, 1422714235, https://doi.org/10.1039/C0CP00811G, 2010.

Peeters, J., Nguyen, T. L., and Vereecken, L.: $\mathrm{HO}_{x}$ radical regeneration in the oxidation of isoprene, Phys. Chem. Chem. Phys., 11, 5935-5939, https://doi.org/10.1039/B908511D, 2009.
Peeters, J., Müller, J.-F., Stavrakou, T., and Nguyen, V. S.: Hydroxyl Radical Recycling in Isoprene Oxidation Driven by Hydrogen Bonding and Hydrogen Tunneling: The Upgraded LIM1 Mechanism, J. Phys. Chem. A, 118, 8625-8643, https://doi.org/10.1021/jp5033146, 2014.

Pollack, I. B., Lerner, B. M., and Ryerson, T. B.: Evaluation of ultraviolet light-emitting diodes for detection of atmospheric $\mathrm{NO}_{2}$ by photolysis - chemiluminescence, J. Atmos. Chem., 65, 111-125, https://doi.org/10.1007/s10874-011-9184-3, 2010.

Russell, A. R., Perring, A. E., Valin, L. C., Bucsela, E. J., Browne, E. C., Wooldridge, P. J., and Cohen, R. C.: A high spatial resolution retrieval of $\mathrm{NO}_{2}$ column densities from OMI: method and evaluation, Atmos. Chem. Phys., 11, 8543-8554, https://doi.org/10.5194/acp-11-8543-2011, 2011.

Russell, A. R., Valin, L. C., and Cohen, R. C.: Trends in OMI $\mathrm{NO}_{2}$ observations over the United States: effects of emission control technology and the economic recession, Atmos. Chem. Phys., 12, 12197-12209, https://doi.org/10.5194/acp-12-121972012, 2012.

Ryerson, T. B., Huey, L. G., Knapp, K., Neuman, J. A., Parrish, D. D., Sueper, D. T., and Fehsenfeld, F. C.: Design and initial characterization of an inlet for gas-phase $\mathrm{NO}_{y}$ measurements from aircraft, J. Geophys. Res.-Atmos., 104, 5483-5492, https://doi.org/10.1029/1998JD100087, 1999.

Schaaf, C. and Wang, Z.: MCD43C3 MODIS/Terra+Aqua BRDF/Albedo Albedo Daily L3 Global 0.05Deg CMG V006., Tech. Rep., https://doi.org/10.5067/MODIS/MCD43C3.006, NASA EOSDIS Land Processes DAAC, 2015.

Stavrakou, T., Peeters, J., and Müller, J.-F.: Improved global modelling of $\mathrm{HO}_{x}$ recycling in isoprene oxidation: evaluation against the GABRIEL and INTEX-A aircraft campaign measurements, Atmos. Chem. Phys., 10, 9863-9878, https://doi.org/10.5194/acp-10-9863-2010, 2010.

Travis, K. R., Jacob, D. J., Fisher, J. A., Kim, P. S., Marais, E. A., Zhu, L., Yu, K., Miller, C. C., Yantosca, R. M., Sulprizio, M. P., Thompson, A. M., Wennberg, P. O., Crounse, J. D., St. Clair, J. M., Cohen, R. C., Laughner, J. L., Dibb, J. E., Hall, S. R., Ullmann, K., Wolfe, G. M., Pollack, I. B., Peischl, J., Neuman, J. A., and Zhou, X.: Why do models overestimate surface ozone in the Southeast United States?, Atmos. Chem. Phys., 16, 1356113577, https://doi.org/10.5194/acp-16-13561-2016, 2016.

Volkamer, R., Platt, U., and Wirtz, K.: Primary and Secondary Glyoxal Formation from Aromatics: Experimental Evidence for the Bicycloalkyl-Radical Pathway from Benzene, Toluene, and p-Xylene, J. Phys. Chem. A, 105, 7865-7874, https://doi.org/10.1021/jp010152w, 2001.

Volkamer, R., Baidar, S., Campos, T. L., Coburn, S., DiGangi, J. P., Dix, B., Eloranta, E. W., Koenig, T. K., Morley, B., Ortega, I., Pierce, B. R., Reeves, M., Sinreich, R., Wang, S., Zondlo, M. A., and Romashkin, P. A.: Aircraft measurements of BrO, IO, glyoxal, $\mathrm{NO}_{2}, \mathrm{H}_{2} \mathrm{O}, \mathrm{O}_{2}-\mathrm{O}_{2}$ and aerosol extinction profiles in the tropics: comparison with aircraft-/ship-based in situ and lidar measurements, Atmos. Meas. Tech., 8, 2121-2148, https://doi.org/10.5194/amt-8-2121-2015, 2015.

Vrekoussis, M., Wittrock, F., Richter, A., and Burrows, J. P.: Temporal and spatial variability of glyoxal as observed from space, Atmos. Chem. Phys., 9, 4485-4504, https://doi.org/10.5194/acp9-4485-2009, 2009. 
Vrekoussis, M., Wittrock, F., Richter, A., and Burrows, J. P.: GOME-2 observations of oxygenated VOCs: what can we learn from the ratio glyoxal to formaldehyde on a global scale?, Atmos. Chem. Phys., 10, 10145-10160, https://doi.org/10.5194/acp-10-10145-2010, 2010.

Wagner, N. L., Brock, C. A., Angevine, W. M., Beyersdorf, A., Campuzano-Jost, P., Day, D., de Gouw, J. A., Diskin, G. S., Gordon, T. D., Graus, M. G., Holloway, J. S., Huey, G., Jimenez, J. L., Lack, D. A., Liao, J., Liu, X., Markovic, M. Z., Middlebrook, A. M., Mikoviny, T., Peischl, J., Perring, A. E., Richardson, M. S., Ryerson, T. B., Schwarz, J. P., Warneke, C., Welti, A., Wisthaler, A., Ziemba, L. D., and Murphy, D. M.: In situ vertical profiles of aerosol extinction, mass, and composition over the southeast United States during SENEX and SEAC ${ }^{4} \mathrm{RS}$ : observations of a modest aerosol enhancement aloft, Atmos. Chem. Phys., 15, 7085-7102, https://doi.org/10.5194/acp-157085-2015, 2015.

Warneke, C., Trainer, M., de Gouw, J. A., Parrish, D. D., Fahey, D. W., Ravishankara, A. R., Middlebrook, A. M., Brock, C. A., Roberts, J. M., Brown, S. S., Neuman, J. A., Lerner, B. M., Lack, D., Law, D., Hübler, G., Pollack, I., Sjostedt, S., Ryerson, T. B., Gilman, J. B., Liao, J., Holloway, J., Peischl, J., Nowak, J. B., Aikin, K. C., Min, K.-E., Washenfelder, R. A., Graus, M. G., Richardson, M., Markovic, M. Z., Wagner, N. L., Welti, A., Veres, P. R., Edwards, P., Schwarz, J. P., Gordon, T., Dube, W. P., McKeen, S. A., Brioude, J., Ahmadov, R., Bougiatioti, A., Lin, J. J., Nenes, A., Wolfe, G. M., Hanisco, T. F., Lee, B. H., LopezHilfiker, F. D., Thornton, J. A., Keutsch, F. N., Kaiser, J., Mao, J., and Hatch, C. D.: Instrumentation and measurement strategy for the NOAA SENEX aircraft campaign as part of the Southeast Atmosphere Study 2013, Atmos. Meas. Tech., 9, 3063-3093, https://doi.org/10.5194/amt-9-3063-2016, 2016.

Wittrock, F., Richter, A., Oetjen, H., Burrows, J. P., Kanakidou, M., Myriokefalitakis, S., Volkamer, R., Beirle, S., Platt, U., and Wagner, T.: Simultaneous global observations of glyoxal and formaldehyde from space, Geophys. Res. Lett., 33, L16804, https://doi.org/10.1029/2006GL026310, 2006.
Wolfe, G. M., Kaiser, J., Hanisco, T. F., Keutsch, F. N., de Gouw, J. A., Gilman, J. B., Graus, M., Hatch, C. D., Holloway, J., Horowitz, L. W., Lee, B. H., Lerner, B. M., LopezHilifiker, F., Mao, J., Marvin, M. R., Peischl, J., Pollack, I. B., Roberts, J. M., Ryerson, T. B., Thornton, J. A., Veres, P. R., and Warneke, C.: Formaldehyde production from isoprene oxidation across $\mathrm{NO}_{x}$ regimes, Atmos. Chem. Phys., 16, 2597-2610, https://doi.org/10.5194/acp-16-2597-2016, 2016.

Yu, K., Jacob, D. J., Fisher, J. A., Kim, P. S., Marais, E. A., Miller, C. C., Travis, K. R., Zhu, L., Yantosca, R. M., Sulprizio, M. P., Cohen, R. C., Dibb, J. E., Fried, A., Mikoviny, T., Ryerson, T. B., Wennberg, P. O., and Wisthaler, A.: Sensitivity to grid resolution in the ability of a chemical transport model to simulate observed oxidant chemistry under high-isoprene conditions, Atmos. Chem. Phys., 16, 4369-4378, https://doi.org/10.5194/acp16-4369-2016, 2016.

Zhu, L., Jacob, D. J., Kim, P. S., Fisher, J. A., Yu, K., Travis, K. R., Mickley, L. J., Yantosca, R. M., Sulprizio, M. P., De Smedt, I., González Abad, G., Chance, K., Li, C., Ferrare, R., Fried, A., Hair, J. W., Hanisco, T. F., Richter, D., Jo Scarino, A., Walega, J., Weibring, P., and Wolfe, G. M.: Observing atmospheric formaldehyde ( $\mathrm{HCHO}$ ) from space: validation and intercomparison of six retrievals from four satellites (OMI, GOME2A, GOME2B, OMPS) with SEAC ${ }^{4} \mathrm{RS}$ aircraft observations over the southeast US, Atmos. Chem. Phys., 16, 1347713490, https://doi.org/10.5194/acp-16-13477-2016, 2016.

Zoogman, P., Liu, X., Suleiman, R., Pennington, W., Flittner, D., Al-Saadi, J., Hilton, B., Nicks, D., Newchurch, M., Carr, J., Janz, S., Andraschko, M., Arola, A., Baker, B., Canova, B., Miller, C. C., Cohen, R., Davis, J., Dussault, M., Edwards, D., Fishman, J., Ghulam, A., Abad, G. G., Grutter, M., Herman, J., Houck, J., Jacob, D., Joiner, J., Kerridge, B., Kim, J., Krotkov, N., Lamsal, L., Li, C., Lindfors, A., Martin, R., McElroy, C., McLinden, C., Natraj, V., Neil, D., Nowlan, C., O'Sullivan, E., Palmer, P., Pierce, R., Pippin, M., Saiz-Lopez, A., Spurr, R., Szykman, J., Torres, O., Veefkind, J., Veihelmann, B., Wang, H., Wang, J., and Chance, K.: Tropospheric emissions: Monitoring of pollution (TEMPO), J. Quant. Spectrosc. Ra., 186, 17-39, https://doi.org/10.1016/j.jqsrt.2016.05.008, 2016. 